\section{Safety Considerations Regarding the Use of Propane and Other Liquefied Gases as Coolants for Rapid Freezing Purposes}

Keith P. Ryan and Malcolm I. Liddicoat

Marine Biological Association of the U.K, The Laboratory

Liquid propane and similar coolants are used in the rapid freezing of biological specimens. These coolants form explosive gas mixtures with air, with a 14,000-fold increase in volume over that of the liquid. The liquefied gases have high vapour pressures and, unless they are maintained below their flashpoint, the vapour above them will reach ignitable concentrations. The flashpoint of liquid propane is $-104^{\circ} \mathrm{C}$. Ethane has a higher vapour pressure, and vapour mixed with air above liquid ethane can be ignited at a coolant temperature of $-130^{\circ} \mathrm{C}$. The danger is minimized if the coolant is maintained near its freezing point and under a nitrogen atmosphere, in a fume cupboard. Liquid nitrogen evaporates to a 690 -fold increase in volume at room temperature. It is important to ventilate the working area, especially when cryo-sectioning in a small room, otherwise there is a possibility of asphyxiation.

\section{INTRODUCTION}

Liquefied propane is being used increasingly for rapidly cooling biological specimens: as this, and similar coolants, can form explosive gas mixtures it is essential to consider relevant safety matters. Some aspects were mentioned recently by Elder et al. (1982) and Silvester et al. (1982), and a fuller discussion is given by Robards \& Sleytr (1985). These references should be consulted by prospective users of cryo-methods.

This note gives further details, particularly with regard to the flammability hazard. While gases such as propane are potentially very dangerous they can be used routinely, providing the hazards are appreciated and precautions are taken to minimize them.

The use of propane, ethane, and mixtures of propane and isopentane (now named 2-methylbutane) can be divided into three phases: (1) liquefaction, (2) cooling activities and (3) disposal.

\section{(1) Liquefaction}

Gas data sheets and information on normal safe handling procedures should be obtained from the gas suppliers, also advice on the handling of cryogens (for example, the BOC Gases publication entitled Care with Cryogenics). Flammable gases must be stored outdoors, because valves leak when worn or damaged.

Liquefaction should be done in a fume cupboard with a spark-protected fan. The gas should be piped in from outdoors; where this is not practicable the gas bottle should be returned outdoors immediately after liquefaction. Protective clothing should be worn, as discussed by the authors cited above. Suitable warning notices should be displayed.

Personnel must be appraised of first aid for cryogen burns; this is to immerse the affected area in lukewarm water and then to apply a cold compress. Medical assistance should be sought for anything worse than a minor burn.

Propane, or ethane, should be condensed slowly in thin copper tubing immersed in liquid nitrogen and collected in a cooled receptacle, after Moberger et al. (1954). The end of the delivery tube should not be immersed in the liquefied gas, especially when gas flow is stopped, because backflow can occur followed by violent vaporization.

\section{(2) Use for Cooling Purposes}

After liquefaction the coolant is collected in, or transferred to, the precooled freezing device. It is cooled by liquid nitrogen and held under an inert atmosphere of nitrogen gas, at a temperature near its freezing point. This enhances cooling efficiency (Costello, 1980; Elder et al, 1982; Ryan et al, 1987); also, in this state the coolant is below its flash point and its vapour pressure is greatly reduced (see Table 1).

It is important to maintain cooling by liquid nitrogen and to monitor coolant temperature. An over-temperature alarm set below the boiling point of the coolant is recommended. The apparatus should not be left unattended.

Coolant temperature can be maintained by a small cartridge heater. The power supply constitutes a possible ignition source and it should be situated either in a spark-protected module or outside the fume cupboard. Electrical safety should be ascertained by qualified personnel.

A magnetic stirrer can accelerate temperature adjustment, although it constitutes another possible ignition source. Under normal operating conditions, in a fume cupboard, vapour formation

$\begin{array}{lrrrrrrrrr}\text { Methane } & -182.6 & -187 & -161.5 & 5.3 & 15.0 & -205.9 & -195.5 & -181.4 & -161.5 \\ \text { Ethane } & -183.2 & -130 & -88.6 & 3.0 & 12.5 & -159.5 & -142.9 & -119.3 & -88.6 \\ \text { Propane } & -189.7 & -104 & -42.1 & 2.1 & 9.5 & -128.9 & -108.5 & -79.6 & -42.1 \\ \text { n-Butane } & -138.4 & -60 & -0.5 & 1.9 & 8.5 & -101.5 & -77.8 & -44.2 & -0.5 \\ \text { iso-Pentane } & -159.9 & -56 & 27.8 & 1.4 & 7.6 & -82.9 & -57.0 & -20.2 & 27.8 \\ \text { Nitrogen } & -209.8 & & -195.8 & & & & & & \\ \text { Oxygen } & -218.4 & & -182.9 & & & & & & \\ \text { Diethylether } & -116.3 & -40 & 34.6 & 1.8 & 36.5 & -74.3 & -48.1 & -11.5 & 34.6 \\ \text { Acetone } & -95.3 & -20 & 56.5 & 2.6 & 12.8 & -59.4 & -31.1 & 7.7 & 56.5 \\ \text { Methanol } & -93.9 & 12 & 64.9 & 6.7 & 36.5 & -44.0 & -16.2 & 21.2 & 64.9 \\ \text { Ethanol } & -117.3 & 13 & 78.4 & 3.3 & 19.1 & -31.3 & -2.3 & 34.9 & 78.4\end{array}$

Note: the flashpoint for methane is below its melting point; solid methane has a vapour pressure of $40 \mathrm{mmHg}$ at $-187.7^{\circ} \mathrm{C}$.

Table 1. Physical characteristics of flammable compoints commonly used in cryotechnique, and transition temperatures for nitrogen and oxygen. ( $T_{\mathrm{mp}}$ melting point; $T_{\mathrm{fp}}$ flashpoint; $T_{b p}$ boiling point). The flashpoint is the temperature at which the vapour concentration above a flammable compound, in contact with air, attains the lower flammability limit. The solvents are used as freeze-substitution media. Data for methane and butane, commonly used in laboratories, are shown for comparison. Data taken from the Handbook of Chemistry and Physics, 65th edn, 1984, CRC Press, Cleveland, Ohio. Flashpoints taken from L. Bretherick, Handbook of Reactive Chemical Hazards, 1975, Butterworths, London at the working temperature is negligible. The impeller shown by Elder et al., (1982) could be used although, again, the motor could constitute a possible ignition source.

A major hazard is mechanical instability of the freezing

Flammability Vapour pressure $(\mathrm{mmHg})$ supported at temperature shown

\section{$T_{\text {mp }} \quad T_{\text {tp }} \quad T_{\text {bp }}$}

limits (\%)

760

1.5

7.8

34.6

8.4 apparatus; it must resist accidental toppling, because this would produce a cloud of explosive gas. The explosive volumes derivable from just $1.0 \mathrm{ml}$ of the liquefied gas are shown in Table 2. These volumes cannot be regarded as being precise, because the thermophysical constants vary according to source.

The build-up of flammable gases can be detected with a sensor; such a device was used by Silvester et al. (1982). It should be noted that some battery-operated models only sample the atmosphere every few minutes.

Coolants maintained below $-183^{\circ} \mathrm{C}$ can condense atmospheric oxygen. This danger was recognized by Stephenson (1954) and is more likely when using pentane/propane mixtures (Bell, 1952; Jehl et al., 1981); these are cooled directly by liquid nitrogen, with no heating. The risk is minimized if the cooling chamber is continually flushed by liquid nitrogen boil-off.

\section{(3) Disposal}

The simplest method of disposal is to allow the coolants to sources. It is imperative that the extractor fan is not turned off, for example, by a night watchman; notices should be displayed. Anevaporate safely in the fume cupboard, after removing all ignition 
other method is to transport the coolant outdoors and pour it slowly onto a hard surface, ensuring there are no ignition sources nearby. If the coolant is poured onto soil the gas can linger in the ground for long periods. Discharge of static electricity should not occur in the area.

\section{DISCUSSION}

The coolants are relatively safe when maintained near their freezing point and under an inert atmosphere, unless they are overturned or splashed onto the operator. The danger derives from any gas accumulating in the room, the potential explosive volumes of which can be calculated from Table 2 .

In our experience little coolant is lost by splashing when plunge-cooling; typically, with a $13 \mathrm{~cm}$ deep device containing about $40 \mathrm{ml}$ of coolant (Ryan \& Purse, 1985) about $3 \mathrm{ml}$ may be lost over several high velocity plunges. The coolant will settle to a constant level thereafter, unless continually replenished. A similar situation may be expected with the very efficient Reichert KF8O device.

Freezing by the propane-jet method presents a different situation. The operation of the Baizers QFD 101 device was improved recently, resulting in a delivery of about $50 \mathrm{ml}$ of liquid propane per operation (Haggis, 1986). With the expansion factor of up to 14,619 (Table 2) this $50 \mathrm{ml}$ could mix with air to form an explosive volume of 7301 , if incorrectly vented.

It is salutory to note that 1.0 I of liquid nitrogen produces about $690 \mid(0.69$ $\mathrm{m}^{3}$ ) of gas at room temperature. The importance of maintaining ventilation is obvious, particularly when cryo-sectioning in a small room: there is a real danger of asphyxiation.

Much of the above also applies to the use of the various Freons, although they are not Inflammable. However, there is growing concern over their use and their part in possibly destroying the ozone layer of the Earth. They are currently banned in aerosols in the U.S.A. and Scandinavia (Glenny, 1987).

\section{ACKNOWLEDGMENT}

We are grateful to Prof. Hellmuth Sitte and Dr. Klaus Neumann of the University of Homburg-Saar, F.R.G., for drawing our attention to the hazard of liquid nitrogen evaporation during cryo-sectioning.

\section{NOTE ADDED IN PROOF}

We are grateful to the Health and Safety Executive, Bristol, for suggesting: (1) that volumes of up to $200 \mathrm{ml}$ of liquefied flammable coolant may be handled, (2) no cylinder equipped with a liquid outlet is used, (3) disposal is done on a bed of pebbles rather than on a hard surface, in case there is a gradient towards the person doing the disposing.

We are also grateful for proofs from a forthcoming book in which, among other Important safety information, data are given regarding the hazard of

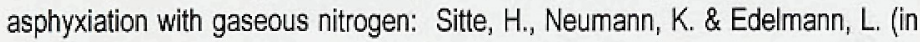

\begin{tabular}{lccccc}
\hline & $\begin{array}{c}\text { Density } \\
\text { at } T_{\text {bp }} \\
(\mathrm{g} / \mathrm{ml})\end{array}$ & $\begin{array}{c}\text { Spec. vol. } \\
\text { at } 20^{\circ} \mathrm{C} \\
(\mathrm{ml} / \mathrm{g})\end{array}$ & $\begin{array}{c}\text { Gas vol. at } 20^{\circ} \mathrm{C} \\
\text { from } 1 \mathrm{ml} \text { at } T_{\text {bp }}(\mathrm{ml})\end{array}$ & \multicolumn{2}{c}{ Explosive volumes (m) } \\
& & & & & \\
Methane & 0.43 & 1480.0 & 636 & 12,000 & 4240 \\
Ethane & 0.54 & 799.0 & 431 & 14,366 & 3448 \\
Propane & 0.58 & 530.6 & 307 & 14,619 & 3231 \\
n-Butane & 0.60 & 399.5 & 239 & 12,578 & 2811 \\
iso-Pentane & 0.62 & 1.6 & 152 & 10,857 & 2000 \\
Nitrogen & 0.80 & 861.5 & 689 & &
\end{tabular}

Note: The volume of vapour from iso-pentane was calculated using the vapour pressure curve, which reveals a vapour pressure of $0.736 \mathrm{~atm}$ at $20^{\circ} \mathrm{C}$. One gram mole (MW 72.15 ) would produce 17.71 of vapour (pure); $1 \mathrm{ml}$ would produce $152 \mathrm{ml}$ of vapour, which yields $10,857 \mathrm{ml}$ of gas mixture on dilution to the lower flammability limit.

Table 2. Calculation of explosive volumes of gas dirived from $1.0 \mathrm{ml}$ of liquefied gas. The volumes are calculated for the concentrations concomitant with the flammability limits in Table 1. The volume of gas dirived from liquid nitrogen is also shown. Density and specific volume data taken from BOC Special Gases catelogue. press) Safety rules for cryopreparation. In: Ciyotechniques in Biological Electron Microscopy (ed. by R. A. Steinbrecht and K. Zierold), pp.285-289. Springer Verlag, Heidelberg.

\section{REFERENCES}

Bell, L.G.E. (1952) The application of freezing and drying techniques in cytology. Int. Rev. Cytol. 1, 35-63.

Costello, M.J. (1980) Ultra-rapid freezing of thin biological samples. Scanning Electron Microscopy, 2, 361-370.

Elder, H.Y., Gray, C.C., Jardine, A.G., Chapman, J.N. \& Biddlecombe, W.H. (1982) Optimum conditions for cryo-quenching of small tissue blocks in liquid coolants. $\mathrm{J}$. Microsc. 126, 45-61.

Glenny, M. (1987) America attacks Europe over stratospheric ozone. New Sci 113 (1550), 17.

Haggis, G.H. (1986) Study of the conditions necessary for propane-jet freezing of fresh biological tissues without detectable ice formation. J. Microsc. 143, 275-282.

Jehi, B., Bauer, R., Dorge, A. \& Rick, R. (1981) The use of propane/isopentane mixtures for rapidly freezing biological specimens. J. Microsc 123, 307-309.

Moberger, G., Lindstrom, B. \& Anderson, L. (1954) Freeze-drying with a modified GlickMalmstrom apparatus. Exp. Cell Res. 6, 228-237.

Robards, A.W. \& Sleytr, U.B. (1985) Low temperature methods in biological electron microscopy. In: Practical Methods in Electon Microscopy, Vol.10 (ed. by A. M. Glauert) Elsevier, Amsterdam.

Ryan, K.P. \& Purse, D.H. (1985) A simple plunge-cooling device for preparing biological specimens for cryo-techniques. Mihroskopie (Wien), 42, 247-251.

Ryan, K.P., Purse, D.H., Robinson, S.G. \& Wood, J.W. (1987) The relative efficiency of cryogens used for plunge-cooling biological specimens. J. Microsc. 145, $89-96$.

Silvester, N.R., Marchese-Ragona, S. \& Johnston, D.N. (1982) The relative efficiency of various fluids in the rapid freezing of protozoa. J. Microsc. 128, 175-186.

Stephenson, J.L. (1954) Caution in the use of liquid propane for freezing biological speci mens. Nature, 174, 235

Reprinted from the Journal of Microscopy (Royal Microscopical Society), Vol. 147 Part 3, pp. $337-340,1987$

\section{Modern Coating Solutions for Today's EM Sample Prep Needs}

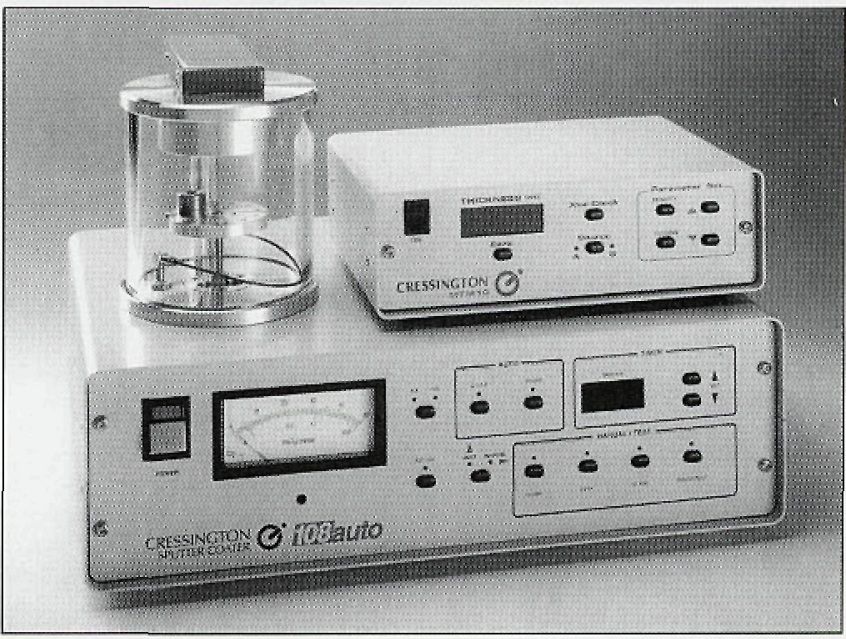

Compact modern desktop systems with fast cycle times. Carbon and sputtering systems for all SEM, FE-SEM and TEM applications.

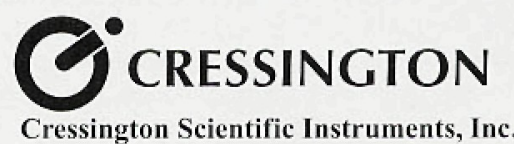

508 Thomson Park Drive, Cranberry Twp., PA 16066

TEL 800-755-1781 / 412-772-0220 FAX 412-772-0219

Website: www.cressington.com 